\title{
Cervical and anal HPV infection and dysplasia in HIV-infected women
}

\author{
EA Stier*2, R Tandon ${ }^{1}$, AS Baranoski ${ }^{1}$, F Huang ${ }^{1}$ and O Vragrovic ${ }^{2}$
}

Address: ${ }^{1}$ Center for Infectious Diseases, Boston University Medical Center, Boston, Massachusetts, USA and ${ }^{2}$ Obstetrics and Gynecology, Boston University Medical Center, Boston, Massachusetts, USA

* Corresponding author

from I I th International Conference on Malignancies in AIDS and Other Acquired Immunodeficiencies (ICMAOI): Basic, Epidemiologic, and Clinical Research

Bethesda, MD, USA. 6-7 October 2008

Published: 17 June 2009

Infectious Agents and Cancer 2009, 4(Suppl 2):P40 doi:10.1 I86/1750-9378-4-S2-P40

This abstract is available from: http://www.infectagentscancer.com/content/4/S2/P40

(C) 2009 Stier et al; licensee BioMed Central Ltd.

\section{Background}

HIV-infected women are at increased risk of cervical HPV infection and neoplasia. We investigated whether HIVinfected women are also at high risk for HPV infection of the anal canal and anal dysplasia.

\section{Methods}

We performed a pilot, prospective, observational study on $100 \mathrm{HIV}$-infected women presenting for routine HIV care. Subjects were interviewed and underwent cervical and anal testing with cytology and HPV with Hybrid Capture 2 assay (Digene Corporation, Gaithersburg, MD). High resolution anoscopy (HRA) or colposcopy were performed if indicated and subjects with high grade dysplasia were referred for treatment. Secondary analyses were performed to assess for associated risk factors for abnormal cervical or anal cytology or HPV infection such as CD4 Tcell count using SPSS for Windows, version 15.0.

\section{Results}

The average age of the subjects was 41 years and 78 percent of the women were currently on highly active antiretroviral therapy.

The prevalence of high-risk HPV infection in the cervix was 24 percent and cervical cytological abnormality was 21.6 percent. Of the 24 patients with cervical HPV infection, 15 (62.5\%) had cervical cytological abnormalities. (Fisher Exact Test, $\mathrm{p}=0.0001$ ).
The prevalence of high risk HPV infection in the anus was 16 percent and anal cytological abnormality was 17 percent. Of the 16 patients with anal HPV infection, 10 (62.5\%) had anal cytological abnormalities (Fisher Exact Test, $\mathrm{p}=0.0001$ ).

Eleven of 24 women (46\%) who had high risk HPV in the cervix also had high risk HPV detected in the anal canal (Fisher Exact Test, p = 0.0001). Eight of 21 women (38 percent) who had abnormal cervical cytology also had abnormal anal cytology (Fisher Exact Test, p = 0.0001).

Subjects with anal HPV infection (mean CD4 count 349 cells/ $\mu \mathrm{l}$ ) had significantly lower mean CD4 counts compared to subjects without anal HPV infection (mean CD4, 555 cells $/ \mu \mathrm{l}$ ) ( $\mathrm{t}$ test, $\mathrm{p}=0.007)$. Subjects with abnormal anal cytology (mean CD4 393 cells/ $\mu$ l) had significantly lower mean CD4 counts compared with subjects with normal anal cytology (mean CD4, 550 cells/ $\mu$ l) (t-test, p $=0.007)$.

Similarly, subjects with cervical HPV infection were significantly more likely to have lower mean CD4 count (394 cells $/ \mu \mathrm{l})$ compared to those without cervical HPV infection $(564$ cells $/ \mu \mathrm{l})$ (t-test, $\mathrm{p}=.01)$. Subjects with abnormal cervical cytology also had lower mean CD4 count (372 cells $/ \mu \mathrm{l}$ ) compared to women with normal cervical cytology (CD4, 549 cells/ $\mu \mathrm{l})$ (t-test, $\mathrm{p}=.004)$. 
Of the 16 patients who underwent colposcopy, eight had low-grade and five had high-grade cervical or vaginal dysplasia. Of the 11 women who underwent HRA, six had low-grade and three had high-grade anal dysplasia.

\section{Conclusion}

Anal and cervical HPV infections are common in HIVinfected women. HIV-infected women have high rates of anal and cervical dysplasia. These findings provide further data for developing anal cytology screening recommendations for this patient population.

Publish with Bio Med Central and every scientist can read your work free of charge

"BioMed Central will be the most significant development for disseminating the results of biomedical research in our lifetime. " Sir Paul Nurse, Cancer Research UK

Your research papers will be:

- available free of charge to the entire biomedical community

- peer reviewed and published immediately upon acceptance

- cited in PubMed and archived on PubMed Central

- yours - you keep the copyright 